\title{
Management of Biodiversity in Australia
}

\author{
Raymond L. Specht \\ Emeritus Professor of Botany, The University of Queensland, Brisbane, Queensland \\ 4072, Australia \\ E-mail: r.specht@ uqconnect.net
}

Received: October 1, 2014 Accepted: November 10, 2014 Published: December 7, 2014

doi:10.5296/jee.v5i2.6741ＵRL: http://dx.doi.org/10.5296/jee.v5i2.6741

\begin{abstract}
The concept of holistic ecosystem research, termed community-physiology, has gradually developed over the last 150 years. The discipline of community-physiology investigates the physico-chemical processes that determine the structure, growth and biodiversity of plant communities (with associated consumers and decomposers), both above and below ground, in space and time, from the tropical north to the temperate south of Australia. These physico-chemical processes (aerodynamic fluxes - frictional, thermal, evaporative \pm atmospheric salinity - plus available soil water and soil nutrients) need to be clearly enunciated and integrated in 'ecosystem models' in order to predict the effect of perturbations (such as Global Warming, nutrient pollution, invasive biota, fire, overgrazing, etc.) on Australian ecosystems. An increase in global temperatures of $2^{\circ} \mathrm{C}$ is predicted to affect the development of the foliage covers of overstorey and understorey strata resulting in open-forests $\longrightarrow$ woodlands $\longrightarrow$ open-woodlands $\longrightarrow$ tall shrublands $\rightarrow$ low shrublands throughout Australia.

In order to conserve Australian biota for posterity, community-physiologists, ecosystem modelers and environmental impact ecologists must have a deep understanding of the eco-physiology of producers, consumers and decomposers that compose an ecosystem and how these organisms interact with the continually-changing physico-chemical processes in the atmosphere and soil, in space and time.
\end{abstract}

Keywords: Ecosystems, Biodiversity, Community-physiology, Pollution, Global warming 


\section{The Development of Ecosystem Studies in Australia}

The peculiarities of the Australian flora and fauna have excited the interest of amateur and professional biologists ever since collections of Australian plants and animals reached Europe from the voyages of discovery made by Capt. William Dampier (1688), Joseph Banks and Daniel Solander with Capt. James Cook (1770), Jacques-Julien Labillardière with Capt. J. A. B. d'Entrecastreaux (1792-3), Robert Brown with Capt. Matthew Flinders (1801-3), and Leschenault de la Tour with Capt. Nicolas Baudin and François Péron (1802).

Understandably, there was an impelling desire to discover and learn more about these unusual plants and animals. Gradually over the nineteenth century, the most important species were collected and described, grouped into genera, families, orders or phyla. The publication of Charles Darwin's The Origin of Species in 1859 gave new direction to biologists all over the world; many turned their attention towards elucidating the evolutionary relationships of the flora and fauna.

It was at this time that the three senior Australian universities - Sydney (1850), Melbourne (1853), and Adelaide (1874) — were founded. Before long, Departments of Natural History were established in each — Sydney (1882), Melbourne (1854), and Adelaide (1875). These departments fostered the evolutionary study of Aus tralian plants and animals.

Every collector and taxonomist was aware that terrestrial plants and animals were to be found in preferred habitats - mangrove swamp, salt marsh, rainforest, eucalypt forest, brigalow, mallee or mulga scrub, grassland ( \pm overstorey trees), heathland ( \pm overstorey trees), saltbush or spinifex plain, etc. Darwin's ideas on natural selection with the concept of 'survival of the fittest' made biologists realise that these landscape entities were not static, but existed in a dynamic, ever-changing state and that the habitat, plants, and animals which comprised the landscape were interrelated with each other.

Thus in 1859, Saint-Hilaire stated in the introduction to his Histoire générale des règnes organiques that the last volume of his work would be devoted to the subject of ethology the study of the relations of the organisms within the family and the society, in the aggregate and in the community. Unfortunately the last volume was never published and it was ten years later in 1869 that Haeckel proposed the term Oekologie — the relation of the organism to its organic as well as its inorganic environment, particularly its friendly or hostile relations to those animals or plants with which it comes in contact.

In the hundred years following Haeckel's enunciation of the discipline of ecology, the landscape-entity, rather vaguely understood by early collectors and taxonomists, has been defined as the ecosystem - the whole, relatively-stable complex of organisms (both plant and animal) and all the inorganic factors of the environment which influence them (Tansley 1935). The interrelationships of this entity may be illustrated as in the simplified diagram shown in Figure 1. 
FigURE I

A simplified diagram showing the interrelations which exist in the ecosystem.

Plants and Animals

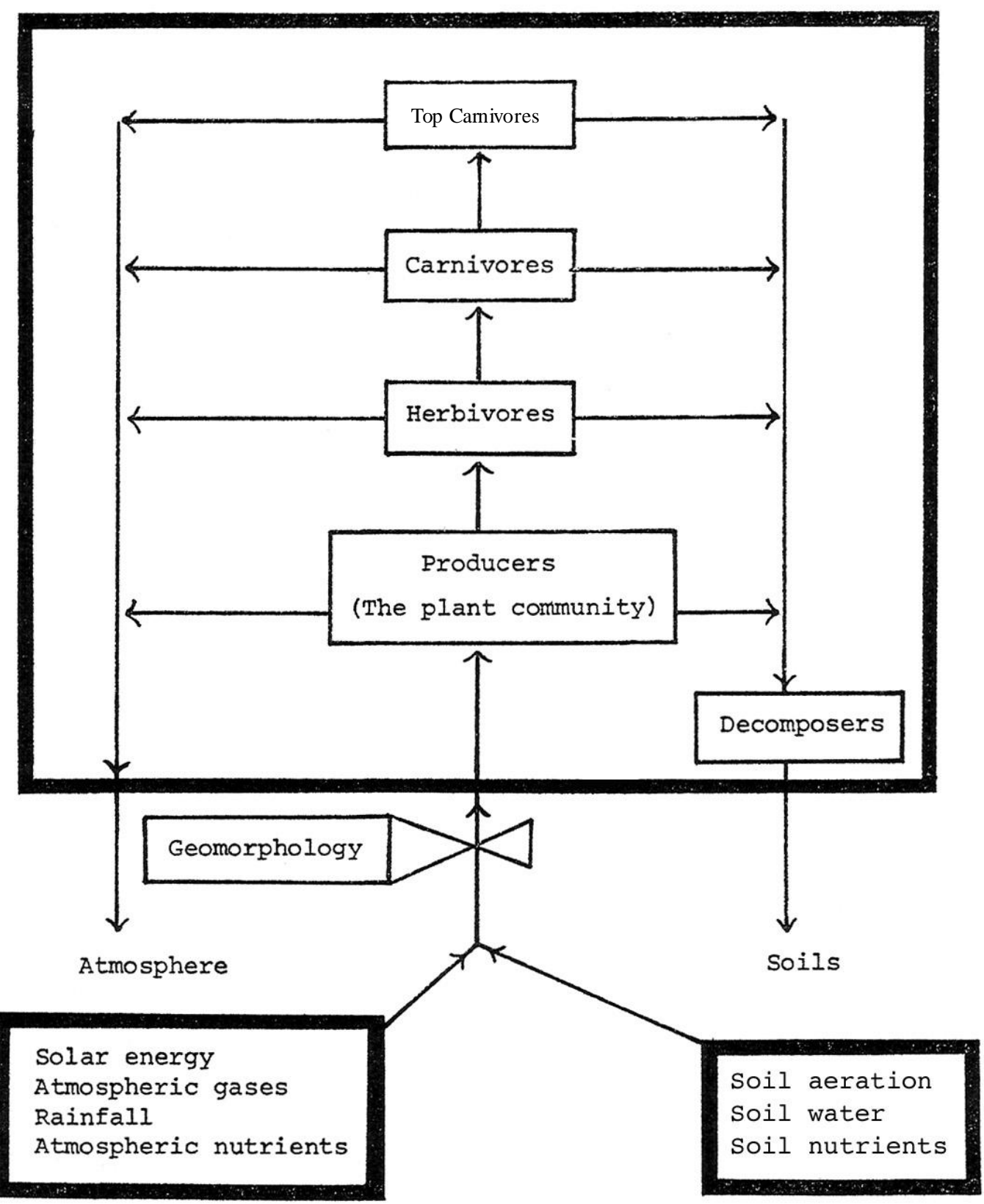


It should be the aim of ecologists to understand the biological, chemical, and physical processes operating between different organisms and between those same organisms and the environment and to understand how these processes are interwoven into a dynamic entity in space and time. In effect, the ecologist is asked to attain the highest level of intellectual thought as expressed in Bloom's Taxonomy of Educational Objectives (1956) in Figure 2.

\section{FigURE 2}

The hierarchy of educational objectives expressed by Bloom (1956). The study of ecology, by definition, is aimed at the highest levels of attainment.

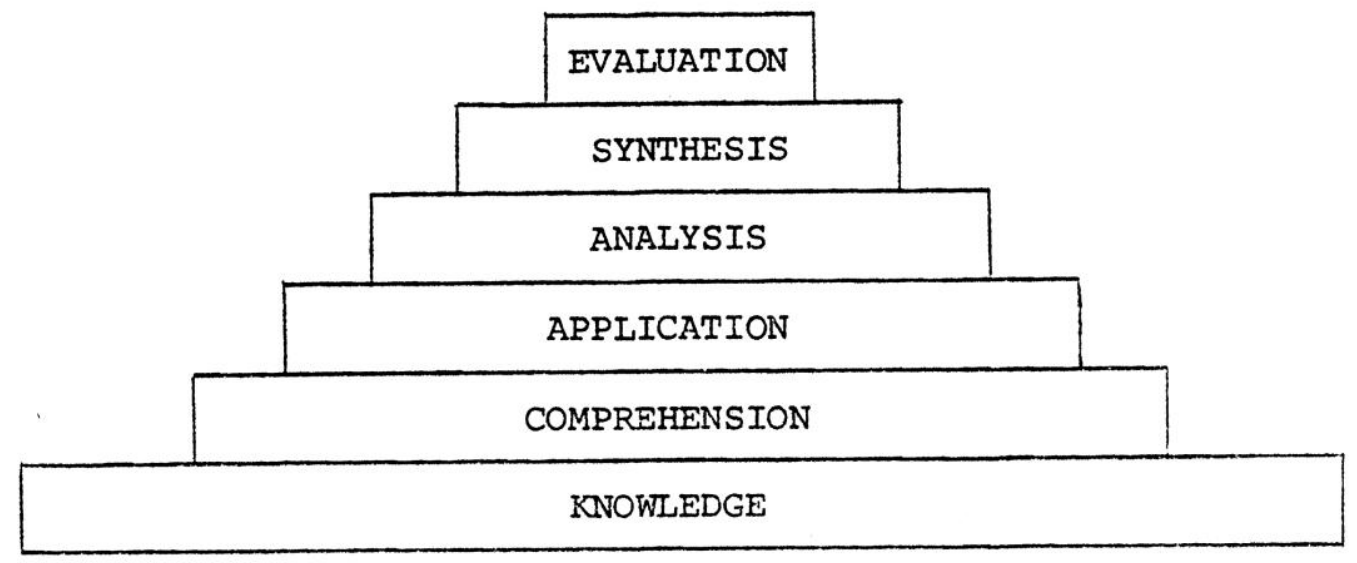

In order to achieve the pinnacle of synthesis and evaluation, the ecologist will find it necessary to amass facts or, more particularly, to explore the processes involved in one or more parts of an ecosystem. But, above all, he should not lose sight of his overall objective - the understanding of how the complete entity, the ecosystem, works and how it, as a whole, may react and adjust to external and internal perturbations.

As Man cannot be excluded from any ecosystem, the ecologist holds a position of extreme responsibility in the World today. It is he alone who should be able to assess the effects of Man's commercial and social enterprises on the landscape, and be able to give advice on the alleviation of disasters that have already occurred. The 'Environmental Impact Statements' are his responsibility. The conservation of the world's renewable (biological) and non-renewable (inorganic) resources should depend on his decisions.

Throughout the world, plant ecology has advanced more rapidly than animal ecology largely because plants are sessile and lend themselves more readily to the study of local distribution patterns than do animals.

By the turn of this century, European plant ecology was well established as a discipline. Grisebach's Die Vegetation der Erde was published in Leipzig in 1872. Schimper's book on Plant-geography upon a Physiological Basis, published in German in 1898, was translated into English in 1903. Warming's book on the Oecology of Plants was published in 1909, based on a book summarising his lectures in Denmark - Plantesamfund (1895). The series 
of volumes Die Vegetation der Erde, edited by Engler and Drude, began to appear; in particular, Ludwig Diels had visited Australia and written Vol. 7 in this series Die Pflanzenwelt von West-Australien südlich des Wendelkreises in 1906. Clements in the United States was formulating his ideas on Plant Succession, published in 1916, 1928 and 1936. Tansley (1935) was active in England, Raunkiaer (1934) in Denmark, and Braun-Blanquet (1932) in Switzerland.

Apart from the visit of Diels, Australia was little influenced by overseas developments in plant ecology apart from the visit of the British Association for the Advancement of Science (BAAS) to Australia in 1914 before the First World War (WW1). It was at this time that T. G. B. Osborn, who had been appointed Professor of Botany, Vegetable Pathology and Parasitology in the University of Adelaide in 1912 as a young man of 25 years wrote an article on the vegetation around Adelaide, South Australia (Osborn 1914). After WW1, Osborn invited R. S. Adamson from the University of Manchester to spend some time in Adelaide during 1922. Osborn, who had previously spent most of his time lecturing, virtually on his own, to the whole of the first degree course in botany, plus acting as Consulting Botanist to the government of South Australia - largely as a plant pathologist - now turned his attention to plant ecology. Two important papers (Adamson \& Osborn 1922, 1924) on the arid ecology of the Ooldea district and on the Eucalyptus forests of the Mount Lofty Ranges appeared with Adamson, who later became Professor of Botany at the University of Cape Town (Adamson 1938). Teaching and research in plant ecology exploded from the Adelaide school. J. G. Wood after graduating with an honours B.Sc. in chemistry, joined Osborn on the staff of the Department of Botany in 1923 and began a series of studies on the water relations, biochemistry and biogeography of South Australian vegetation. Ecological studies were further stimulated by the establishment in 1925 of Koonamore Vegetation Reserve (now the T. G B. Osborn Reserve at Koonamore) in the arid zone of South Australia (Osborn 1928 ; Wood 1936; Hall et al. 1964; Sinclair 2004, 2005).

The ecological approach was strengthened in Adelaide on the establishment of the Waite Agricultural Research Institute in 1924 with research groups in climatology, soils, grassland, weeds, and insect ecology under A. E. V. Richardson, J. A. Prescott, J. Davidson and H. C. Trumble. H. G. Andrewartha, T. O. Browning, R. L. Crocker, N. S. Tiver, and J. A. K. Walker expanded these fields in the 1940s.

The major scientific interests of Prof. J. A. Prescott were in the development, chemistry and physics of Australian soils (Prescott 1936, 1938a, 1938b, 1944, 1949, Prescott \& Pendleton 1952). Plant biochemist, Prof. J. G Wood, was interested in the survival of native plants in the seasonally-droughted, nutrient-poor Australian landscapes (Wood 1925, 1932, 1933a, 1933b, 1934). Prescott understood clearly that research and education should proceed hand-in-hand; in 1947, he wrote to entomologist Charles Birch — "With few exceptions, research must be associated either with teaching or advisory work. The first helps to develop ideas more clearly, the second brings the problems of current importance to the notice of the research worker.” (Stephens \& Quirk 1988, p. 307).

Osborn's influence in plant ecology extended to the University of Sydney in 1928 when he 
became Professor of Botany there from 1928 until 1937, then Professor of Botany in the University of Oxford after the retirement of Professor Tansley. Wood continued to expand the strong ecological tradition established in Adelaide up until his death in 1959. The publication of Wood's handbook on the Vegetation of South Australia in 1937 was a landmark in the development of plant ecology in Australia.

In 1935, the holistic concept of the 'ecosystem' was promoted by A. G. Tansley, Professor of Botany of Oxford University (Tansley 1935). The 'ecosystem' concept, relating climate, soils and vegetation, over time (short- and long-term) was pursued by R. (Bob) L. Crocker of C.S.I.R. Soils Division and the Agronomy Department of the Waite Agricultural Research Institute, together with Professor J. G. Wood of the Botany Department, University of Adelaide (Crocker 1946; Crocker \& Wood 1947). During 1947 and 1948 while on sabbatical leave in Cambridge University and the University of California, Berkeley, Bob Crocker developed the concepts of 'soil genesis and the pedogenic factors' and their interactions with the dynamics of plant communities — in space and time (Crocker 1952). The various eco-physiological facets of the ecosystem were to be explored and integrated by one scientist.

Vegetation = Function (climate, parent material, relief, organisms, time)

This holistic study of the dynamic processes that operate throughout the life cycle - from regeneration to maturity to senescence - of ecosystems in soil-vegetation chronosequences, post-fire succession, secondary succession after disturbance, etc., was initiated in the 1950s as the discipline of community-physiology (Specht \& Rayson 1957; Specht 1963), to be promoted by the International Biological Program, Section PP, Sub-Section Community-Physiological Processes in Terrestrial Ecosystems (Specht 1967).

The discipline of community-physiology attempts to study the processes that determine the complex interrelations of the many plants, animals and micro-organisms that form each ecosystem - quite distinct from descriptive studies of the component species of the whole ecosystem or the study of individual species within an ecosystem, such as eco-physiology and population ecology (Andrewartha \& Birch 1954; Andrewartha 1961). Physico-chemical processes (aerodynamic fluxes, temperature, available soil water and mineral nutrition) determine the structure, growth and biodiversity of intact plant communities (and associated consumers and decomposers) that comprise the diversity of ecosystems in the field.

\section{Evolution of Australian Ecosystems}

Australian ecosystems have evolved on a heritage of Late Cretaceous lateritic soils (Prescott \& Pendleton 1952), rich in kaolinite clay minerals that 'fixes' phosphate and molybdenate ions in an unavailable form within its crystalline lattice. The Gondwanan elements in the flora have persisted for over 50 million years (Hooker 1860; Specht 1958a, 1958b, 1981b, 1981c, 1988b; Clifford \& Simon 1981; Johnson \& Briggs 1981; Specht et al. 1992; Hill et al. 1999). During the Cainozoic, especially about 10 million years ago when Global Warming of $2-5^{\circ} \mathrm{C}$ occurred (Shackleton \& Kennett 1975), the perhumid climate of the Early Tertiary became increasingly arid (Martin 2006), thus subjecting the diverse life-forms in the producer section of each ecosystem to severe aerodynamic stresses (frictional, thermal, evaporative \pm 
atmospheric salinity) as the atmosphere flows over and through the plant community. Seasonal shoot and root growth (also flower and fruit production) of all life-forms within a plant community are determined by aerodynamic fluxes, in conjunction with mineral nutrition. Seasonal rhythms of all consumers and decomposers are intricately entwined with those of the plant species that form an ecosystem. As annual foliage growth (biomass per hectare) of the plant community changes, the biodiversity (number of species per hectare) of the producer, consumer and decomposer sections of each ecosystem shows a concomitant change. Controlled experiments on the effects of water, nutrients, grazing, etc. on the structure, growth and biodiversity of an ecosystem must be maintained for many decades often logistically and economically impossible. It is better to study changes produced in ecosystems along environmental gradients, where 'Mother Nature' has conducted controlled experiments over many centuries.

\section{Training of Community-Physiologists}

It is essential to train scientists in community-physiology to investigate the physico-chemical processes that operate in the whole ecosystem - especially in the unique Australian ecosystems from the arid to the perhumid climatic zones in temperate, subtropical and tropical, also montane Australia - under the impact of the many environmental stresses imposed since European settlement.

Ecosystem Modelling is the course in which the ecologist synthesises and evaluates all the interlocking processes operating in an ecosystem (above and below ground) - as defined by controlled scientific experiments that form the 'major ideas' in all the previous courses. In Ecosystem Modelling, the ecologist is asked to attain the highest level of intellectual thought (Synthesis and Evaluation), as expressed in Bloom's Taxonomy of Educational Objectives (1956), by investigating the impact of perturbations on a variety of ecosystems, from the arid to the perhumid climatic zone, from the temperate to the tropical climatic region (Specht \& Specht 1999).

Even in the 1970s, the training of community-physiologists in Biology Departments of Australian universities was almost impossible (Specht 1976, 1981a). Over the last two decades, ecological studies in Botany Departments - where the complex interactions of the many species in the producer, consumer and decomposer sections of an ecosystem were emphasised - have been submerged within Biology Departments where population ecology dealing with a single species prevail. As well, there has been increasing emphasise on molecular biology, paying less attention to the complex environmental studies that focus on the basic problems of sustainability of ecosystems throughout Australia.

Australian ecosystems (and those of other Gondwanan continents) have evolved on landscapes that are markedly different from the northern part of the world. Basic research on community-physiological processes that operate to determine the structure, growth and biodiversity of ecosystems is essential for scientific management to ensure sustainability far into the future.

The following physico-chemical processes that operate in Australian plant communities have 
been established: -

(1) Phosphorus nutrition - The lateritic soils (widespread across the Gondwanan continents) — and soils derived after degradation — contain a large percentage of kaolonitic clay minerals that 'fix' phosphates within their crystalline lattice. Australian ecosystems have evolved to conserve this essential nutrient - for example, as polyphosphate, stored in granules, during litter decomposition to be hydrolysed later to orthophosphate for transport to growing foliage apices (Coleman \& Specht 1981; Specht et al. 1983). After European settlement, contamination by phosphate-rich litter has led to 'phosphorus toxicity' that causes the gradual degeneration of native plant communities (and associated consumers and decomposers) - a process accelerated by increase in microbial flora such as chytrids, Mundulla Yellows MY-RNA, Phytophthora cinnamomi, etc. (Specht 1963; Ozanne \& Specht 1981; Specht \& Specht 1989d).

The remarkable 'phosphate-fixation' of kaolinite could be used to bind 'phosphate-pollution' - mostly accumulated in the surface $1 \mathrm{~cm}$ of soil - along paths through native vegetation in many Australian ecosytems. (Specht 1981d).

(2) Nitrate versus ammonium nutrition - Solar radiation falling on soil within gaps in native Australian plant communities leads to the formation of nitrate ions - rather than ammonium ions - from decomposing litter (Stewart et al. 1990). Together with phosphate pollution, thin-leaved plants (mostly introduced), with high nitrate reductase activity in their leaves, invade the plant community (Specht \& Clifford 1991).

(3) Sodium, an essential (or toxic) nutrient - The growth of $\mathrm{C} 4$ photosynthetic plants (many Arid Zone chenopods and tropical grasses) requires small quantities of sodium ions blown inland from sea-spray (Brownell 1965; Brownell \& Crossland 1972). In contrast, sodium ions have a toxic effect on $\mathrm{C} 3$ photosynthetic plants reducing growth and species richness of plant communities dominated by these species (Rich 1996; Specht \& Specht 1999; Specht 2007).

(4) Cytoplasmic organelles in desiccated leaves of $\mathbf{C 4}$ grasses (such as Astrebla lappacea) may be restored to normal within a day after rain falls, thus restoring their photosynthetic potential(Doley \& Trivett 1974; Mittelheuser 1977).

(5) Calciphile versus calciphobe nutrition - Calcareous dust composed of aragonite from foraminifera and cockles, blown inland off the exposed coastal shelf during Recent Ice Ages, has induced extensive areas of calciphile mallee vegetation across southern Australia (Parsons 1968, 1969; Parsons \& Specht 1967). The calcitic dust derived from calareous coralline algae in northern Australia, inhibits the development of woody plants on coastal dunes (Specht 1958a; Byrnes et al. 1977), also sea-grasses between coral reefs (Waycott et al. 2007).

(6) Foliage shoots are initiated annually when the temperature in the boundary layer surrounding a shoot apex lies between critical ranges for nanotherms, microtherms, mesotherms, macrotherms, and megatherms (Specht \& Rayson 1957; Specht \& Brouwer 1975; Specht et al. 1981; Specht A. 1985; Specht 1986; Hegarty 1990). These boundary layer 
temperatures can be determined (1) in the gradient from the temperate to the tropical regions (Specht 1981f) and (2) in the air entrapped between leaves of various density of packing on dicotyledonous shoot or in monocotyledonous clumps (Specht \& Yates 1990; Specht et al. 1991).

(7) Aerody namic fluxes (frictional, thermal, evaporative) abrade the annual foliage growth at the edges of all plants within a plant community so that the sum of Foliage Projective Covers of overstorey $\left(\mathrm{FPC}_{\mathrm{o}}\right)$ and understorey $\left(\mathrm{FPC}_{\mathrm{u}}\right)-\Sigma\left(\mathrm{FPC}_{\mathrm{o}}+\mathrm{FPC}_{\mathrm{u}}\right)-$ remains constant in space and time - throughout the life-cycle of the plant community (Specht \& Morgan 1981; Specht 1983; Specht \& Specht 1999; Specht 2000). This balance between overstorey and understorey Foliage Projective Covers determines the Evaporative Coefficient $(\mathrm{k})$ - the monthly ratio of actual to potential evapotranspiration per available soil water - a constant unaffected by variation in rainfall during the year and between years (Specht 1972a, 1972b, 1981f).

(8) Closed-forests /dry-scrubs on me dian-nutrient soils and closed-heathlands (with tall Proteaceae) on nutrient-poor soils result wherever optimal soil water is available during the short period of annual shoot growth in the overstorey - with the Evaporative Coefficient (k) asymptoting to unity (Specht 1972a, 1981f; Specht \& Specht 1999; Specht \& Moll 2014).

(9) Species richness (number of species per unit area) of plants, vertebrates, and probably invertebrates is correlated with Annual Shoot Growth (per hectare) and Leaf Area Index (area of all leaves per hectare) of the overstorey in a plant community - and thus with the annual fixation of solar enegy by photosynthesis (Braithwaite et al. 1985; Specht A. 1988; Specht \& Specht 1989a, 1989b; Specht et al. 1990, 2006; Specht A. \& Specht 1993, 1994; Specht 1994; Specht \& Tyler 2010; Specht 2012).

A program of undergraduate education for ecologists, community-physiologists and ecosystem modellers — based on 'Major Ideas' for the 'Inquiry Method' of teaching (such as developed for the Australian Biological Sciences Curriculum Study (B.S.C.S.) 'The Web of Life' by Morgan et al. (1967) - has been developed so that the material can be adapted for discovery-learning by undergraduates in various regions of Australia: -

Specht, R. L. \& Specht, A. (1999). Australian Plant Communities. Dynamics of Structure, Growth and Biodiversity. Oxford University Press, Melbourne.

The first half of this book deals with the description of Australian ecosystems (Specht et al. 1974, 1995), their biogeography since the Late Cretaceous, and Aboriginal impact on these ecosystems - based on long-term studies (up to 50 years duration), such as: -

Subtropical rainforest (Hegarty 1990; Lamb 1980; Doley et al. 1987; Stewart et al. 1990; Specht A. 1988; Specht \& Specht 2010; Specht 2007).

Montain ash tall open-forest (Ashton 1976; Langford 1976).

Eucalypt open-forest (Specht \& Specht A. 1989a, 1989b, 1999, 2010; Specht \& Rundel 1990; Specht A. \& Specht 1993, 1994; Specht et al. 2006; Qld Dept Environment \& Resource Management 2010). 
Brigalow open-forest (Johnson 1964, 2004; Russell et al. 1967; Connor et al. 1971).

Mulga tall shrublands (Burrows \& Beale 1969).

Heathlands (Specht et al. 1958; Specht 1963; Heddle \& Specht 1975; Specht 1981c; Specht \& Specht 1989c).

Chenopod low shrublands (Wood 1936; Hall et al. 1964; Carrodus \& Specht 1965; Noble 1977; Noble \& Crisp 1980; Sinclair 2004, 2005).

Mitchell grass open-grassland (Roe 1962; Williams \& Roe 1975; Doley \& Trivett 1974).

Sub-alpine grassland (Carr \& Turner 1959; Williams \& Ashton 1987a, 1987b, 1988; Wimbush \& Costin 1979, 1983).

Wetlands (Specht A. 1988-2005; Specht 1990, 2009).

Coastal dunes (Specht 1997).

Coastal wetlands (Saenger et al. 1977).

The second half of the book deals with dynamic community-physiological processes that determine the structure, growth and biodiversity of plant communities (with associated consumers and decomposers), and ecosystem modelling of these processes.

Chapter 9 - Energetics; Chapter 10 - Temperature; Chapter 11 - Evaporative aerodynamics; Chapter 12 - Available water; Chapter 13 - Eco-physiological leaf attributes; Chapter 14 - Waterlogging; Chapter 15 - Nutrient deficiencies; Chapter 16

- Nutrient toxicities; Chapter 17 - Biodiversity and energetics; Chapter 18 Monitoring; Chapter 19 - Scientific management.

\section{Conclusions}

An understanding of community-physiological processes is essential for the scientific management of the structure, growth and biodiversity of Australia's diverse ecosystems from the arid to the perhumid zones in the temperate south to the tropical north of the continent. These physico-chemical processes need to be clearly defined and integrated in 'ecosystem models' in order to predict the effect of perturbations such as nutrient pollution, invasive biota, fire, overgrazing and Global Warming (Specht 1988a; Specht \& Specht 1995, 1999).

\section{References}

Adamson, R. S. (1938). The Vegetation of South Africa. British Empire Vegetation Committee, London, England.

Adamson, R. S., \& Osborn, T. G B. (1922). On the ecology of the Ooldea District. Transactions of the Royal Society of South Australia, 46, 539-564.

Adamson R. S., \& Osborn, T. G. B. (1924). The ecology of the Eucalyptus forests of the Mount Lofty Ranges (Adelaide District), South Australia. Transactions of the Royal Society 
of South Australia, 48, 87-144.

Andrewartha, H. G. (1961). Introduction to the Study of Animal Populations. Methuen, London, England. (2 ${ }^{\text {nd }}$ ed. 1970. Chapman \& Hall, London.)

Andrewartha H. G, \& Birch, L. C. (1954). The Distribution and Abundance of Animals. University of Chicago Press, Chicago, U.S.A.

Ashton, D. H. (1976). The development of even-aged stands of Eucalyptus regnans F. Muell. Australian Journal of Botany, 24, 397-414. http://dx.doi.org/10.1071/BT9760397

Bloom, B. S. (Ed.) (1956). Taxonomy of Educational Objectives. McKay, New York, U.S.A.

Braithwaite, R. W., Winter, J. W., Taylor, J. A., \& Parker, B. S. (1985). Patterns of diversity and structure of mammalian assemblages in the Australian tropics. Australian Mammalogist, 8, 171-186.

Braun-Blanquet, J. (1932). Plant Sociology. McGraw-Hill Book Co., New York, U.S.A.

Brownell, P. F. (1965). Sodium as an essential micro-nutrient element for a higher plant (Atriplex vesicaria). Plant Physiology, 40, 460-468. http://dx.doi.org/10.1104/pp.40.3.460

Brownell P. F., \& Crossland, C. J. (1972). The requirement for sodium as a micro-nutrient by species having the C4 dicarboxylic photosynthetic pathway. Plant Physiology, 49, 794-797. http://dx.doi.org/10.1104/pp.49.5.794

Burrows, W. H., \& Beale, I. F. (1969). Structure and association in the mulga (Acacia aneura) lands of south-western Queensland. Australian Journal of Botany, 17, 539-552. http://dx.doi.org/10.1071/BT9690539

Byrnes, N. B., Everist, S. L., Reynolds, S. T., Specht, A., \& Specht, R. L. (1977). Vegetation of Lizard Island, North Queensland. Proceedings of the Royal Society of Queensland, 88, $1-15$.

Carr, S. G M., \& Turner, J. S. (1959). The ecology of the Bogong High Plains. II. Fencing experiments in grassland. Australian Journal of Botany, 7, 34-63. http://dx.doi.org/10.1071/BT9590034

Carrodus, B. B., \& Specht, R. L. (1965). Factors affecting the relative distribution of Atriplex vesicaria and Kochia sedifolia (Chenopodiaceae) in the arid zone of South Australia. Australian Journal of Botany, 13, 419-433. http://dx.doi.org/10.1071/BT9650419

Clements, F. E. (1916). Plant Succession. Carnegie Institution Washington Publication No. 242.

Clements, F. E. (1928). Plant Succession and Indicators. H. W. Wilson Co., New York, U.S.A.

Clements, F. E. (1936). Nature and structure of the climax. Journal of Ecology, 24, 252-283. http ://dx.doi.org/10.2307/2256278 
Clifford H. T., \& Simon, B. K. (1981). The biogeography of Australian grasses. In: Ecological Biogeography of Australia. (Ed. A. Keast) pp. 537-554, Junk, The Hague, Netherlands. http://dx.doi.org/10.1007/978-94-009-8629-9_18

Coleman R. G, \& Specht, R. L. (1981). Mineral nutrition of heathlands; The possible role of polyphosphate in the phosphorus economy of heathland species. In: Ecosystems of the Worlds. Vol. 9B. Heathlands and Related Shrublands. Analytical Studies. (Ed. R. L. Specht) pp. 197-207, Elsevier, Amsterdam, Netherlands.

Connor, D. J., Tunstall, B. R., \& Van Den Driessche, R. (1971). An analysis of photosynthetic response in a brigalow forest. Photosynthetica, 5, 218-225.

Crocker, R. L. (1946). Post-Miocene Climatic and Geologic History and its Significance in Relation to the Genesis of the Major Soil Types of South Australia. Council of Scientific and Industrial Research Bulletin No. 193, Melbourne, Australia.

Crocker, R. L. (1952). Soil genesis and the pedogenic factors. Quarterly Review of Biology, 27, 139-168. http://dx.doi.org/10.1086/398872

Crocker R. L., \& Wood, J. G. (1947). Some historical influences on the development of the South Australian vegetation communities and their bearing on concepts and classification in ecology. Transactions of the Royal Society of South Australia, 71, 91-136.

Darwin, C. (1859). Origin of Species. Murray, London, England.

Diels, L. (1906). Die Vegetation der Erde. Vol. 7. Die Pflanzenwelt von West-Australien südlich des Wendekreises. Wilhelm Engelmann, Leipzig, Germany.

Doley D., \& Trivett, N. A. B. (1974). Effects of low water potentials on transpiration and photosynthesis in Mitchell grass (Astrebla lappacea). Australian Journal of Plant Physiology, 1, 539-550. http://dx.doi.org/10.1071/PP9740539

Doley, D., Yates, D. J., \& Unwin, G. L. (1987). Photosynthesis in an Australian rainforest tree, Argyrodendron peralatum, during the rapid development and relief of water deficits in the dry season. Oecologia, 74, 441-449. http://dx.doi.org/10.1007/BF00378943

Grisebach, A. R. H. (1872). Die Vegetation der Erde. Wilhelm Engelmann, Leipzig, Germany.

Haeckel, E. (1869). Entwicklungsgang und Aufgaben der Zoologie. Jenaische Zeitschrift, 5, 353.

Hall, E. A. A., Specht, R. L., \& Eardley, C. M. (1964). Regeneration of the vegetation on Koonamore Vegetation Reserve, 1926-1962. Australian Journal of Botany, 12, 205-264.

Heddle, E. M., \& Specht, R. L. (1975). Dark Island heath (Ninety-Mile Plain, South Australia). 8. The effect of fertilizers on composition and growth, 1950-1972. Australian Journal of Botany, 23, 151-164.

Hegarty, E. E. (1990). Leaf life-span and leafing phenology of lianes and associated trees 
during a rainforest succession. Journal of Ecology, 78, 300-312.

Hill, R. S., Truswell, E. M., McLoughlin, S., \& Dettmann, M. E. (1999). Evolution of the Australian flora: Fossil evidence. In: Flora of Australia. Vol. 1. Introduction. pp. 251-320, Second Edition, CSIRO Publishing, Melbourne, Australia.

Hooker, J. D. (1860). On the flora of Australia, being part of an Introductory Essay to Flora Tasmaniae," The botany of the Antarctic voyage of H. M. discovery ships Erebus and Terror, in the years 1839-1843., Part III, 1, xxc vii-cxxviii.

Johnson L. A. S., \& Briggs, B. G. (1981). Three old southern families - Myrtaceae, Proteaceae and Restionaceae. In: Ecological Biogeography of Australia. (Ed. A. Keast) pp. 427-469. Junk, The Hague, Netherlands.

Johnson, R. W. (1964). Ecology and Control of Brigalow in Queensland, Queensland Department of Primary Ind ustries, Brisbane, Australia.

Johnson, R. W. (2004). Vegetation survey of the Brigalow Research Station, Theodore, Queensland. Proceedings of the Royal Society of Queensland, 111, 39-61.

Lamb, D. (1980). Soil nitrogen mineralization in a secondary rainforest succession. Oecologia, 47, 257-263.

Langford, K. J. (1976). Changes in yield of water following a bushfire in a forest of Eucalyptus regnans. Journal of Hydrology, 29, 87-114.

Martin, H. A. (2006). Cainozo ic climatic change and the development of the arid vegetation in Australia. Journal of Arid Environments, 66, 533-563.

Mittelheuser, C. J. (1977). Rapid ultrastructural recovery of water stressed leaf tissue. Zeitschrift für Pflanzenphysiologie, 82, 458-461.

Morgan, D. G, Best, E., Lee, A., Nicholas, J., \& Pitman, M. (Eds) (1967). Biological Science: The Web of Life. Australian Academy of Science, Canberra, Australia.

Noble, I. R. (1977). Long-term biomass dynamics in an arid chenopod shrub community at Koonamore, South Australia. Australian Journal of Botany, 25, 639-653.

Noble, I. R., \& Crisp, M. D. (1980). Germination and growth models of short-lived grass and forb populations based on long-term photo-point data at Koonamore, South Australia. Israel Journal of Botany, 28, 195-210.

Osborn, T. G B. (1914). Sketches of vegetation at home and abroad. VIII. Notes on the flora around Adelaide, South Australia. New Phytologist, 13, 109-121.

Osborn, T. G. B. (1928). The Koonamore Vegetation Reserve. Journal of the Council of Scientific \& Industrial Research, 1, 365-368.

Ozanne P. G. \& Specht, R. L. (1981). Mineral nutrition of heathlands. Phosphorus toxicity. In: Ecosystems of the World. Vol. 9b. Heathlands and Related Shrublands. Analytical Studies. (Ed. R. L. Specht) pp. 209-213, Elsevier, Amsterdam, Netherlands. 
Parsons, R. F. (1968). Ecological aspects of the growth and mineral nutrition of three mallee species of Eucalyptus. Oecologia Plantarum, 3, 121-136.

Parsons, R. F. (1969). Physiological and ecological tolerances of Eucalyptus incrassata and E. socialis to edaphic factors. Ecology, 50, 386-390.

Parsons R. F., \& Specht, R. L. (1967). Lime chlorosis and other factors affecting the distribution of Eucalyptus on coastal sands in southern Australia. Australian Journal of Botany, 15, 95-105.

Prescott, J. A. (1936). The climatic control of the Australian deserts. Transactions of the Royal Society of South Australia, 60, 93-95.

Prescott, J. A. (1938a). The climate of tropical Australia in relation to possible agricultural occupation, Transactions of the Royal Society of South Australia, 62, 229-240.

Prescott, J. A. (1938b). Indices in agricultural climatology. Journal of the Australian Institute of Agricultural Science, 4, 33-40.

Prescott, J. A. (1944). A soil map of Australia. Council of Scientific \& Industrial Research (Aust.) Bulletin. No. 177, Melbourne, Australia.

Prescott, J. A. (1949). A climatic index for the leaching factor in soil formation. Journal of Soil Science, 1, 9-19.

Prescott J. A., \& Pendleton, R. L. (1952). Laterite and Lateritic Soils. Commonwealth Bureau of Soil Science \& Technology Communication No. 47, London.

Queensland Department of Environment and Resource Management (2010). Land cover changes in Queensland 2008-09: A Statewide Landcover and Trees Study (SLATS) Report 2011, Department of Environment and Resource Management, Brisbane, Australia.

Raunkiaer, C. (1934). The Life Form of Plants and Statistical Plant Geography. Oxford University Press, Oxford, England.

Rich, A. (1996). What is Littoral about Rainforest? B. Appl. Sc. Hons. Thesis, Southern Cross University, Lismore, New South Wales, Australia.

Roe, R. (1962). 1. Mitchell grass plant counts - Gilruth Plains. 2. Mitchell grass pasture Gilruth Plains. CSIRO (Aust.) Division of Plant Industry, Field Station Record, vol. 1, pp. 19-28.

Russell, J. S., Moore, A. W. \& Coaldrake, J. E. (1967). Relationships between subtropical and semiarid forest of Acacia harpophylla (brigalow), microrelief and chemical properties of associated gilgai soils. Australian Journal of Botany, 15, 481-498.

Saenger, P., Specht, M. M., Specht, R. L. \& Chapman, V. J. (1977). Mangal and coastal salt marsh communities in Australasia. In: Ecosystems of the World. Vol. 1. Wet Coastal Formations. (Ed. V. J. Chapman), pp. 293-345, Elsevier, Amsterdam, Netherlands.

Saint-Hilaire, I. C. (1859). Histoire Générale des Règnes Organiques. Paris, France. 
Schimper, A. F. W. (1903). Plant Geography upon a Physiological Basis. Clarendon Press, Oxford, England.

Shackleton, N. J. \& Kennett, J. P. (1975). Palaeo-temperature history of the Cenozoic and the initiation of Antarctic glaciation: Oxygen and carbon isotope analyses in DSDP sites 277, 279, 281. In: Initial Reports of the Deep Sea Drilling Project 29. pp. 743-755, United States Government Printing Office, Washington, USA.

Sinclair, R. (2004). Persistence of dead trees and fallen timber in the Arid Zone: 76 years of data from the T.G.B. Osborn Vegetation Reserve, Koonamore, South Australia. Rangeland Journal, 26, 111-122.

Sinclair, R. (2005). Long-term changes in vegetation, gradual and episodic on the T.G.B. Osborn Vegetation Reserve, Koonamore, South Australia (1926-2002). Australian Journal of Botany, 53, 283-296.

Specht, A. (1985). Temperature Effects on Eucalypt Shoot Growth in the Brisbane Region. Ph.D. Thesis, University of Queensland, St Lucia, Queensland, Australia.

Specht, A. (1988). Big Scrub Conservation Strategy. Vol. 2. Resource Material. (Ed. Planners North Pty Ltd) pp. 1-72. N.S.W. National Parks \& Wildlife Service, Sydney, New South Wales, Australia.

Specht, A. (1988-2005). Vegetation Monitoring of Eighteen Mile Swamp, North Stradbroke Island. Reports No. 1-9. Centre for Coastal Management, Southern Cross University, Lismore, New South Wales, Australia.

Specht, A., \& Specht, R. L. (1993). Species richness and canopy productivity of Australian plant communities. Biodiversity \& Conservation, 2, 152-167.

Specht, A., \& Specht, R. L. (1994). Biodiversity of overstorey trees in relation to canopy productivity and stand density in the climatic gradient from warm temperate to tropical Australia. Biodiversity Letters, 2, 39-45.

Specht, A., \& Specht, R. L. (2001). Australia: Biodiversity of ecosystems. In: Encyclopedia of Biodiversity. (Ed. S. Levin), Academic Press, San Diego, California, U.S.A., pp. 307-324.

Specht, A., \& Specht, R. L. (2011). Australia: Biodiversity of ecosystems. In: Encyclopedia of Biodiversity. Second Edition. (Ed. S. Levin), Elsevier, Kidlington, U.K.

Specht, R. L. (1958a). Climate, geology, soils and plant ecology of the northern portion of Arnhem Land. In: Records of the American-Australian Scientific Expedition to Arnhem Land. Vol. 3. Botany and Plant Ecology. (Eds R. L. Specht \& C. P. Mountford), pp. 333-414, Melbourne University Press, Melbourne, Australia, 1958.

Specht, R. L. (1958b). Geographical relationships of the flora of Arnhem Land. In: Records of the American-Australian Scientific Expedition to Arnhem Land. Vol. 3. Botany and Plant Ecology. (Eds R. L. Specht and C. P. Mountford) pp. 415-478, Melbourne University Press, Melbourne, Australia. 
Specht, R. L. (1963). Dark Island heath (Ninety-Mile Plain, South Australia). 7. The effect of fertilizers on composition and growth, 1950-1960. Australian Journal of Botany, 11, 67-94.

Specht, R. L. (1967). The photosynthesis of plant communities in relation to structure, physiology and environment. Photosynthetica, 1, 132-143.

Specht, R. L. (1972a). Water use by perennial, evergreen plant communities in Australia and Papua New Guinea. Australian Journal of Botany, 20, 273-299.

Specht, R. L. (1972b). The Vegetation of South Australia. Government Printer, Adelaide, South Australia.

Specht, R. L. (1976). The history and contemporary state of life sciences in Australian universities. II. Terrestrial ecology. The Australian University, 14, 99-113.

Specht, R. L. (1981a). Australia. In: Handbook of Contemporary Developments in World Ecology. (Eds E. J. Kormondy \& J. F. McCormick) pp. 387-415, Greenwood Press, Westport, Conn., U.S.A.

Specht, R. L. (1981b). Major vegetation formations in Australia. In: Ecological Biogeography of Australia. (Ed. A. Keast) pp. 163-297, Junk, The Hague, Netherlands.

Specht, R. L. (1981c). Evolution of the Australian flora: Some generalisations. In: Ecological Biogeog raphy of Australia. (Ed. A. Keast) pp. 783-806, Junk, The Hague, Netherlands.

Specht, R. L. (1981d). Conservation: Australian heathlands. In: Ecosystems of the World. Vol. 9B. Heathlands and Related Shrublands. Analytical Studies. (Ed. R. L. Specht) pp. 235-240, Elsevier, Amsterdam, Netherlands.

Specht, R. L. (1981e). Responses to fire in heathlands and related shrublands. In: Fire and the Australian Biota. (Eds A. M. Gill, R. H. Groves \& I. R. Noble) pp. 395-415, Australian Academy of Science, Canberra, Australia.

Specht, R. L. (1981f). Growth indices - Their rôle in understanding the growth, structure and distribution of Australian vegetation. Oecologia, Berlin, 50, 347-356.

Specht, R. L. (1983). Foliage projective covers of overstorey and understorey strata of mature vegetation in Australia. Australian Journal of Ecology, 8, 433-439.

Specht, R. L. (1986). Functioning of tropical plant communities: Phenology. In: Tropical Plant Communities. Their Resilience, Functioning and Management in Northern Australia. (Eds H. T. Clifford \& R. L. Specht) pp. 78-90, Utah Foundation \& University of Queensland, Botany Department, St Lucia, Queensland, Australia, 1986.

Specht, R. L. (1988a). Geosphere-biosphere interaction in terrestrial ecosystems. In: Global Change. (Ed. K. D. Cole), pp. 169-176. Australian Academy of Science, Canberra, Australia.

Specht, R. L. (1988b). Origin and evolution of terrestrial plant communities in the wet-dry tropics of Australia. Proceedings of the Ecological Society of Australia, 15, 19-30.

Specht, R. L. (1990). Forested wetlands in Australia. In: Ecosystems of the World. Vol. 16. 
Wetland Forests. (Eds A. E. Lugo, M. M. Brinson \& Sandra Brown), pp. 387-406, Elsevier, Amsterdam, Netherlands.

Specht, R. L. (1994). Species richness of vascular plants and vertebrates in relation to canopy productivity. In: Plant-Animal Interactions in Mediterranean-Type Ecosystems. (Eds M. Arianoutsou \& R. H. Groves) pp. 15-24, Kluwer Scientific Publishers, Dordrecht, Netherlands.

Specht, R. L. (1997). Ecosystem dynamics in coastal dunes of eastern Australia. In: Ecosystems of the World. Vol. 2C. Dry Coastal Ecosystems. General Aspects. (Ed. E. van der Maarel), pp. 483-495, Elsevier, Amsterdam, Netherlands.

Specht, R. L. (2000). Savanna woodland vegetation in the South-East District of South Australia: the influence of evaporative aerodynamics on the foliage structure of the understorey invaded by introduced annuals. Austral Ecology, 25, 588-599.

Specht, R. L. (2007). Species richness of rainforest stands on non-serpentinite and serpentinite substrates in the Rockhampton - Marlborough area of Central Queensland. Proceedings of the Royal Society of Queensland, 113, 17-35.

Specht, R. L. (2009). Structure and species richness in wetland continua on sandy soils in subtropical and tropical Australia. Austral Ecology, 34, 761-772.

Specht, R. L. (2012). Biodiversity of terrestrial ecosystems in tropical to temperate Australia. International Journal of Ecology, Vol. 2012, Article ID 359892, 15 pp., 2012. <doi: $10.1155 / 2012 / 359892>$

Specht, R. L. \& Brouwer, Y. M. (1975). Seasonal shoot growth of Eucalyptus spp. in the Brisbane area of Queensland (with notes on shoot growth and litter fall in other areas of Australia). Australian Journal of Botany, 23, 459-474.

Specht R. L., \& Clifford, H. T. (1991). Plant invasion and soil seed banks: Control by water and nutrients. In: Biogeography of Mediterranean Invasions. (Eds R. H. Groves and F. di Castri) pp. 191-204, SPB Academic Publishing, Amsterdam, Netherlands.

Specht, R. L., \& Moll, E. J. (2014). Structure and alpha biodiversity of major plant communities in South Africa, a close biogeographical relation of Australia. Journal of Environment and Ecology, 5(2).

Specht, R. L. \& Morgan, D. G. (1981). The balance between the foliage projective covers of overstorey and understorey strata in Australian vegetation. Australian Journal of Ecology, 6, 193-202.

Specht, R. L. \& Rayson, P. (1957). Dark Island heath (Ninety-Mile Plain, South Australia). 1. Definition of the ecosystem. 3. The root systems. Australian Journal of Botany, 5, 52-85, 103-114.

Specht, R. L. \& Rundel, P. W. (1990). Sclerophylly and foliar nutrient status of Mediterranean-climate plant communities in southern Australia. Australian Journal of Botany, 
$38,459-474$.

Specht, R. L. \& Specht, A. (1989a). Species richness of overstorey strata in Australian plant communities. The influence of overstorey growth rates. Australian Journal of Botany, 37, 321-336.

Specht R. L., \& Specht, A. (1989b). Species richness of sclerophyll (heathy) plant communities in Australia. The influence of overstorey cover. Australian Journal of Botany, 37, 337-350.

Specht, R. L. \& Specht, A. (1989c). Canopy structure in Eucalyptus-dominated communities in Australia along climatic gradients. Acta Oecologia, Oecologia Plantarum, 10, 191-202.

Specht, R. L. \& Specht, A. (1995). Global warming: Predicted effects on structure and species richness of Mediterranean ecosystems in southern Australia. In: Time Scales of Biological Responses to Water Constraints: The Case of Mediterranean Biota. (Eds J. Roy, J. Aronson \& F. di Castri), pp. 215-237, SPB Academic Publishing, Amsterdam, Netherlands.

Specht, R. L. \& Specht, A. (1999). Australian Plant Communities. Dynamics of Structure, Growth and Biodiversity. Oxford University Press, Melbourne, Australia. (Paperback Edition 2002)

Specht R. L., \& Specht, A. (2010). The ratio of foliar nitrogen to foliar phosphorus: a determinant of leaf attributes in life-forms of subtropical and tropical plant communities. Australian Journal of Botany, 58, 527-538.

Specht, R. L. \& Tyler, M. J. (2010). The species richness of vascular plants and amphibia in major plant communities in temperate and tropical Australia: Relationship with annual biomass production. International Journal of Ecology, Volume 2010, Article ID 635852, 17 pages.

Specht, R. L. \& Yates, D. J. (1990). Climatic control of structure and phenology of foliage shoots in dicotyledonous overstorey and understorey strata of subtropical plant communities in eastern Australia. Acta Oecologia, 11, 215-233.

Specht, R. L., Rayson, P. \& Jackman, M. E. (1958). Dark Island heath (Ninety-Mile Plain, South Australia). 6. Pyric succession: Changes in composition, coverage, dry weight and mineral nutrient status. Australian Journal of Botany, 6, 59-88.

Specht, R. L., Roe, E. M. \& Boughton, V. H. (Eds) (1974). Conservation of Major Plant Communities in Australia and Papua New Guinea. Australian Journal of Botany Supplement No. 7, Melbourne, Australia.

Specht, R. L., Rogers, R. W. \& Hopkins, A. J. M. (1981). Seasonal growth and flowering rhythms: Australian heathlands. In: Ecosystems of the World. Vol. 9B. Heathlands and Related Shrublands. Analytical Studies. (Ed. R. L. Specht) pp. 5-13, Elsevier, Amsterdam, Netherland.

Specht, R. L., Moll, E. J., Pressinger, F. \& Sommerville, J. (1983). Moisture regime and 
nutrient control of seasonal growth in mediterranean ecosystems. In: Mediterranean-Type Ecosystems. The Role of Nutrients. (Eds F. J. Kruger, D. T. Mitchell \& J. U. M. Jarvis) pp. 120-132, Springer-Verlag, Berlin, Germany.

Specht, R. L., Grundy, R. I. \& Specht, A. (with Ruhama Berliner) (1990). Species richness of plant communities: relationship with community growth and structure. Israel Journal of Botany, 39, 465-480.

Specht, R. L., Yates, D. J., Sommerville, J. E. M. \& Moll, E. J. (1991). Foliage structure and shoot growth in heathlands in the mediterranean-type climate of southern Australia and South Africa. Ecologia Mediterranea, 16, 195-207.

Specht, R. L., Dettmann, M. E. \& Jarzen, D. M. (1992). Community associations and structure in the Late Cretaceous vegetation of southeast Australasia and Antarctica. Palaeogeography, Palaeoclimatology, Palaeoecology, 94, 283-309.

Specht, R. L., Specht, A., Whelan, M. B. \& Hegarty, E. E. (1995). Conservation Atlas of Plant Communities in Australia. Southern Cross University, Lismore, New South Wales, Australia.

Specht, R. L., Batianoff, G. N. \& Reeves, R. D. (2006). Vegetation structure and biodiversity along the eucalypt forest to rainforest continuum on the serpentinite soil catena in sub-humid Central Queensland, Australia. Austral Ecology, 32, 394-407.

Stephens C. G. \& Quirk, J. P. (1988) James Arthur Prescott 1890 - 1987. Historical Records of Australian Science, 7, 299-313.

Stewart, G. R., Gracia, C. A., Hegarty, E. E. \& Specht, R. L. (1990). Nitrate reductase activity and chlorophyll content in sun leaves of subtropical closed-forest (rainforest) and open-forest communities. Oecologia, 82, 544-551.

Tansley, A. G. (1935). The use and abuse of vegetational concepts and terms. Ecology, 16, 284-307.

Warming, E. (1895). Plantesamfund. Grundträk af den ökologiske Plantegeografi. Copenhagen, Denmark.

Waycott, M., Collier, C., McMahon, K., Ralph, P., McKenzie, L., Udy, J. \& Grech, A. (2007). Vulnerabilty of seagrasses in the Great Barrier Reef to climate change. In: Climate Change and the Great Barrier Reef. A Vulnerabilty Assessment. pp. 194-235, Australian Institute of Marine Science, Townsville, Queensland, Australia.

Williams, O. B. \& Roe, R. (1975). Management of arid grasslands for sheep: Plant demography of six grasses in relation to climate and grazing. Proceedings of the Ecological Society of Australia, 9, 142-156.

Williams, R. J. \& Ashton, D. A. (1987a). The composition, structure and distribution of heathland and grassland communities in the subalpine tract of the Bogong High Plains, Victoria. Australian Journal of Ecology, 12, 57-71. 
Williams, R. J. \& Ashton, D. A. (1987b). The effects of disturbance and grazing by cattle on the dynamics of heathland and grassland communities on the Bogong High Plains, Victoria. Australian Journal of Botany, 35, 413-431.

Williams, R. J. \& Ashton, D. A. (1988). Cyclical patterns of regeneration in subalpine heathland communities on the Bogong High Plains, Victoria. Australian Journal of Botany, 36, 605-619.

Wimbush, D. J. \& Costin, A. B. (1979). Trends in vegetation at Kosciusko. I. Subalpine grazing trials 1957-1971. II. Subalpine range transects 1959-1978. III. Alpine range transects 1959-1978. Australian Journal of Botany, 27, 741-787, 789-831, 833-871.

Wimbush, D. J. \& Costin, A. B. (1983). Trends in drainage characteristics in the subalpine zone at Kosciusko. Proceedings of the Ecological Society of Australia, 12, 143-154.

Wood, J. G. (1925). Selective absorption of chlorine ions and absorption of water by leaves in the genus Atriplex. Australian Journal of Experimental Biology \& Medical Science, 2, 45-56.

Wood, J. G. (1932). The physiology of xerophytism of Australian plants. The carbohydrate metabolism of plants with tomentose succulent leaves. Australian Journal of Experimental Biology \& Medical Science, 10, 89-95.

Wood, J. G. (1933a). Carbohydrate changes in leaves of sclerophyll plants. Australian Journal of Experimental Biology \& Medical Science, 11, 139-150.

Wood, J. G (1933b). The nitrogen metabolism of the leaves of Atriplex nummularium. Australian Journal of Experimental Biology \& Medical Science, 11, 237-252.

Wood, J. G (1934). The physiology of xerophytism in Australian plants. The stomatal frequencies, transpiration and osmotic pressures of sclerophyll and tomentose-succulent leaved plants. Journal of Ecology, 22, 69-87.

Wood, J. G. (1936). Regeneration of the vegetation on the Koonamore Vegetation Reserve, 1926 to 1936. Transactions of the Royal Society of South Australia, 60, 96-111.

Wood, J. G. (1937). The Vegetation of South Australia. Government Printer, Adelaide, Australia.

\section{Copy right Disclaimer}

Copyright for this article is retained by the author(s), with first publication rights granted to the journal.

This is an open-access article distributed under the terms and conditions of the Creative Commons Attribution license (http://creativecommons.org/licenses/by/3.0/). 